Acta vet. scand. $1976,17,233-243$.

From the Department of Medicine I, the Department of Clinical Biochemistry and the Department of Pathology, Royal Veterinary College, Stockholm, Sweden.

\title{
HEMATOLOGICAL AND BIOCHEMICAL ANALYSES OF BLOOD AND SERUM IN PIGS WITH REGIONAL ILEITIS WITH SPECIAL REFERENCE TO THE PATHOGENESIS
}

By

Kjell Martinsson, Lars Ekman and Lennart Jönsson

\begin{abstract}
MARTINSSON, K., L. EKMAN and L. JÖNSSON: Hematological and biochemical analyses of blood and serum in pigs with regional ileitis with special reference to the pathogenesis. Acta vet. scand. 1976, 17, 233-243. - Biochemical and hematological analyses of blood and serum were performed in pigs with regional ileitis and in wasting pigs with a negative necropsy. In sera from pigs with regional ileitis the levels of total protein, albumin, transferrin, alkaline phosphatase and zinc were significantly decreased compared with normal pigs of the same age. The number of white blood cells, and the concentration of cortisol and $\alpha_{1}$-antitrypsin were significantly increased. In wasting pigs with early signs of regional ileitis or with a negative necropsy the same blood changes were observed but to a less degree. It was concluded that a wasting syndrome after weaning may precede regional ileitis. Concerning the etiology of regional ileitis the significance of malabsorption and wasting syndrome in combination with invasion of intestinal intercellular microorganisms is discussed.
\end{abstract}

regional ileitis; wasting pigs; alkaline phosphatases; serum proteins; zinc; cortisol.

During the past few years several investigations on regional ileitis in pigs have been performed. Almost all of these focused the pathological aspects of the disease, including light and electron microscopy investigations and bacteriological studies (i.e. Dodd 1968, Rowland \& Lawson 1974, Lawson \& Rowland 1974). Clinical chemistry of the disease seems to have received little attention. Nielsen (1966) found very low levels of albumin in three cases of regional ileitis. Furthermore, he showed that during a period with profuse diarrhea, these pigs had a hyper- 
catabolism of albumin due to a gastrointestinal protein loss. In another investigation (Martinsson et al. 1974), sera from 10 pigs with regional ileitis were analysed. It was shown that these pigs had low levels of total serum protein and albumin. Furthermore, the levels of zinc and alkaline phophatases were low. The significance of these alterations was discussed in view of the etiology and pathogenesis of the disease. There were some indications that zinc was involved in the pathogenesis of regional ileitis. Therefore, experiments were started in which such pigs were treated by adding zinc to food or water (Martinsson $\& E k$ man 1974). The results were encouraging, and these treatments have since been used in Sweden on many farms with wasting pigs appearing after weaning. Since the pathogenesis of regional ileitis and the role of zinc are not clarified, it was considered to be of interest to perform more detailed hematological and biological analyses of serum from diseased pigs.

\section{Animals}

\section{MATERIAL AND METHODS}

Pigs, about 10 weeks old, from four different farms were investigated. The pigs were weaned at an age of about six weeks. Blood samples were taken from the anterior vena cava before necropsy. All pigs, except the controls, had the clinical appearance of a wasting syndrome which had started after weaning. According to the results of the necropsy, which included electronmicroscopic examination, the animals were divided into four groups (Jönsson \& Martinsson 1976):

1. Pigs with large lesions of regional ileitis in which intracellular microorganisms were detected $(n=10)$.

2. Pigs with no or very small macroscopic signs of regional ileitis but in which intracellular microorganisms were detected in affected epithelium $(n=8)$.

3. Pigs with no lesions of regional ileitis and in which no intracellular microorganisms were found $(n=8)$.

4. Normal pigs of the same age as the experimental groups $(n=8)$.

\section{Hematological and biochemical analyses}

Hematological analyses were performed immediately after sampling. Serum was stored at $-70^{\circ} \mathrm{C}$ before analysis. The following methods were used: 
Le u c o y te count: Electronic blood cell counter (Celloscope 401, AB Lars Ljungberg \& Co, Stockholm, Sweden).

Hemoglobin: Spectrophotometrically as cyanmethhemoglobin.

Pla s m a rea-N: The Hyland UN-TEST (Hyland Div., Travenol Laboratories, Costa Mesa, Calif. USA).

Tot a l cholest e r o l: Method employing the Lieberman-Burchard reaction (Huang et al. 1961).

Alkaline phosphatase, aspartate aminotransferase (ASAT) and alanine aminotransferase (ALAT): Methods recommended by the Scandinavian Committee on Enzymes (1974) using LKB Reaction Rate analyzer and reagents from AB Kabi, Stockholm, Sweden.

Creatinine phosphokinase (CPK): According to Forster et al. (1970) with the LKB Reaction Rate Analyzer and reagents from Boehringer Mannheim, Germany.

Serum zinc and serum copper: Atomic absorption spectrophotometer (Perkin-Elmer 403) according to methods recommended by the manufacturer (Perkin-Elmer Manual, March 1971).

P l a s m a c orti s o l: A rapid competitive protein binding technique (Richkind \& Edqvist 1973).

Serum el e ctrophoresis: Separation on cellulose acetate membranes in a Microzone $\mathrm{R} 101$ with TRIS-buffer, $\mathrm{pH}$ 8.9. Evaluation in a Densitometer R 110 (Beckman, Fullerton, Calif. USA). Total protein was determined with the Biuret-method.

\section{Immunological quantitations of proteins}

The levels of $\alpha_{1}$-antitrypsin, $\alpha_{2}$-macroglobulin and transferrin were determined by electroimmunoassay as described by Laurell (1966). Samples of $5 \mu \mathrm{l}$ were analysed by electrophoresis in $1 \%$ agarose in $0.024 \mathrm{M}$ diemal buffer, $\mathrm{pH}$ 8.6, containing monospecific antisera. The electrophoresis was performed with a constant voltage of $2 \mathrm{v} / \mathrm{cm}$ for $20 \mathrm{hrs}$. Antisera against swine $\alpha_{1}$ antitrypsin and $\alpha_{2}$-macroglobulin were produced in rabbits as described by Martinsson \& Carlström (1976). Antiserum against swine transferrin was prepared as described by Thorén-Tolling $\&$ Martinsson (1974). The levels of the different proteins were expressed as percentage of a standard serum (serum from a pig, 10 weeks old) which was tested in four dilutions on every plate.

\section{RESULTS}

All animals which were used in the present investigation were necropsied, and the results of the post-mortem examination will be reported (Jönsson \& Martinsson 1976). The same grouping of 
T a ble 1. Hematological analyses of the different groups of pigs. Values significantly differing from normals are noticed as * ${ }^{*}$ * or ${ }^{* *}$ $($ mean $\pm s)$.

\begin{tabular}{lcccc}
\hline & $\begin{array}{c}\text { Hemoglobin } \\
\text { g/100 ml }\end{array}$ & $\begin{array}{c}\text { WBC } \\
\text { per } \mu \mathrm{l}\end{array}$ & Neutrofils & Lymfocytes \\
\cline { 5 - 5 } & & & & absolute numbers per $\mu \mathrm{l}$ \\
\hline $\begin{array}{l}\text { Group 1 } \\
\text { (terminal ileitis) }\end{array}$ & $9.7 \pm 1.8^{\star *}$ & $31,500 \pm 7,500^{\star}$ & $15,100 \pm 2,700^{\star \star \star}$ & $13,200 \pm 3,000$ \\
$\begin{array}{l}\text { Group 2 } \\
\text { (terminal ileitis, } \\
\text { very early stage) }\end{array}$ & $10.7 \pm 1.0^{*}$ & $29,900 \pm 10,500$ & $9,400 \pm 3,600$ & $11,000 \pm 4,100$ \\
$\begin{array}{l}\text { Group 3 } \\
\text { (wasting pigs, }\end{array}$ & $10.0 \pm 0.5^{\star *}$ & $22,900 \pm 5,300$ & $9,600 \pm 2,100$ & $11,900 \pm 2,000$ \\
$\begin{array}{l}\text { negative necropsy) } \\
\text { Group 4 } \\
\text { (normal pigs) }\end{array}$ & $12.1 \pm 0.6$ & $22,900 \pm 2,800$ & $8,200 \pm 900$ & $12,100 \pm 1,000$ \\
\hline
\end{tabular}

the animals was used in the present investigation according to post-mortem findings.

The results of the blood analyses are summarized in Tables 1-3. The most prominent changes include decreased levels of alkaline phosphatase, total serum proteins, albumin and zinc in the three groups of diseased pigs. The greatest changes are observed in group 1. Regarding alkaline phosphatase, a gradual decrease is observed from group 3 to group 1. In addition to these general changes it was also found that the pigs in groups 1-3 had a significantly lower hemoglobin value than the control animals. In group 1 , increased numbers of white blood cells were also observed. The levels of cholesterol in groups 1 and 3 were decreased in comparison with the normal levels.

From the immunological determination of $\alpha_{1}$-antitrypsin, $\alpha_{2}$ macroglobulin and transferrin, it was found that the levels of transferrin in groups 1 and 3 were significantly decreased compared to the controls. The levels of $\alpha_{1}$-antitrypsin were increased in group 1.

\section{DISCUSSION}

The pigs used in the present investigation were from the same group as used in another study concerning post-mortem changes (Jönsson \& Martinsson 1976). The grouping was made according to the post-mortem findings. The importance of the intra- 


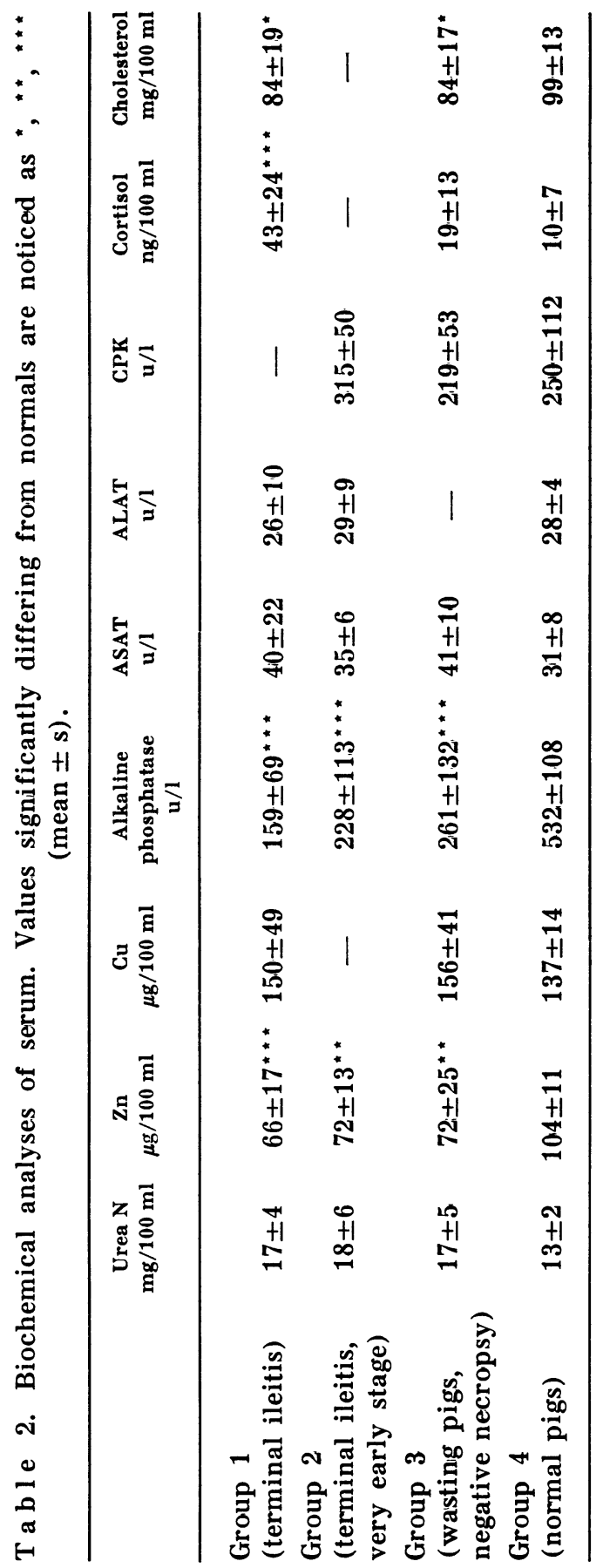




\begin{tabular}{|c|c|c|c|c|}
\hline 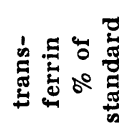 & 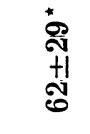 & 1 & \begin{tabular}{l}
$*$ \\
\multirow{2}{*}{} \\
+1 \\
+1 \\
$\infty$
\end{tabular} & 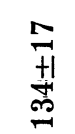 \\
\hline 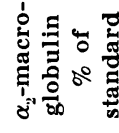 & $\begin{array}{l}\stackrel{8}{+} \\
+1 \\
\stackrel{8}{8}\end{array}$ & 1 & $\begin{array}{l}\mathscr{N} \\
+1 \\
\stackrel{+}{0} \\
\stackrel{\sigma}{0}\end{array}$ & $\begin{array}{l}\infty \\
+1 \\
\infty \\
=\end{array}$ \\
\hline 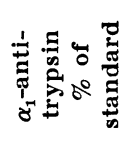 & 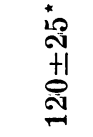 & 1 & $\begin{array}{l}\vec{J} \\
+1 \\
\stackrel{0}{\sigma}\end{array}$ & $\begin{array}{l}\infty \\
+1 \\
\infty \\
\infty\end{array}$ \\
\hline 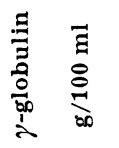 & 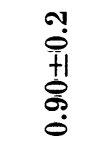 & 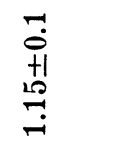 & 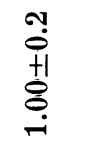 & $\begin{array}{l}\overrightarrow{0} \\
+1 \\
0 \\
\dot{0}\end{array}$ \\
\hline 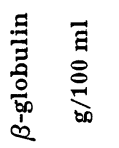 & 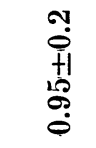 & $\begin{array}{l}-1 \\
\dot{+1} \\
+1 \\
0 \\
0 \\
-1\end{array}$ & $\begin{array}{l}\text { ฯ } \\
0 \\
+1 \\
0 \\
0 \\
0\end{array}$ & 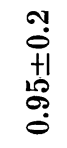 \\
\hline 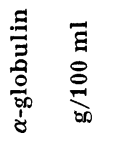 & 苛 & $\begin{array}{l}\stackrel{\infty}{0} \\
\stackrel{\oplus}{+1} \\
\stackrel{\oplus}{\sim}\end{array}$ & 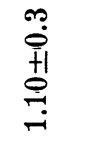 & $\begin{array}{l}\overrightarrow{0} \\
+1 \\
\stackrel{+1}{0}\end{array}$ \\
\hline 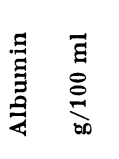 & \begin{tabular}{l}
\multirow{N}{*}{} \\
$\stackrel{0}{+1}$ \\
+1 \\
0 \\
0 \\
0
\end{tabular} & 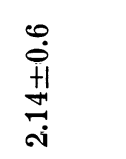 & $\begin{array}{l}\stackrel{*}{*} \\
\dot{0} \\
+1 \\
2 \\
2 \\
i \\
i\end{array}$ & 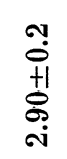 \\
\hline 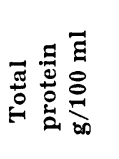 & $\begin{array}{l}* \\
\dot{0} \\
+1 \\
\dot{0} \\
\dot{m} \\
\dot{m}\end{array}$ & $\begin{array}{l}9 \\
0 \\
+1 \\
+1 \\
10 \\
10\end{array}$ & 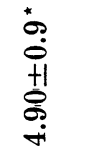 & $\begin{array}{l}10 \\
\stackrel{0}{0} \\
+1 \\
\stackrel{+}{0} \\
\dot{0}\end{array}$ \\
\hline & 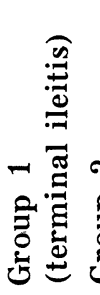 & 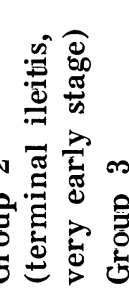 & 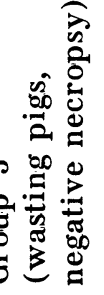 & 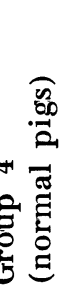 \\
\hline
\end{tabular}


cellular microorganisms found in the ileal epithelium was especially considered.

It should be noted that all experimental pigs had the same main clinical signs which appeared soon after weaning and which included poor growth, wasting appearance and sometimes unspecific eczema on the back. The control pigs were taken from one of the four herds from which the affected pigs were obtained. Diarrhea had been observed only occasionally before or after weaning in the diseased animals.

Hematological findings in pigs from groups $1-3$ included a decreased hemoglobin concentration. This may have been secondary to the wasting process, since it is not likely that such a minor lowering of hemoglobin concentration should be of importance as a predisposing factor for a wasting syndrome. However, pigs with severe regional ileitis also have increased amounts of $\mathrm{WBC}$, indicating an inflammatory reaction which may influence the hemoglobin values.

Pigs with large areas of involvement of regional ileitis showed the greatest change in the blood serum components investigated. The increased concentration of cortisol in pigs of group 1 is an interesting observation but the significance of the finding is difficult to evaluate. It is tempting to relate the low levels of alkaline phosphatase to the comparatively low concentrations of serum zinc. Alkaline phosphatase is a zinc-metallo-enzyme and it has been shown in many investigations that an experimental zinc deficiency will give rise to low alkaline phosphatase activity in blood serum (Prasad et al. 1969, Agergaard \& Palludan 1974, Burch et al. 1975). The question arises as to whether the decreased level of serum zinc is primary or secondary to the onset of regional ileitis. Many of the pigs in groups 1-3 had a nonspecific black eczema on the back and three pigs had typical parakeratosis, the classical sign of zinc deficiency in pigs. However, in a great number of herds investigated it was found that there was no correlation between a low content of zinc in the food and the occurrence of wasting pigs or pigs with regional ileitis (Martinsson \& Ekman, unpublished). This observation speaks in favour of a theory that signs of zinc deficiency are secondary manifestations of the disease.

It was found that pigs with regional ileitis (group 1) had very low levels of albumin (Table 3). One explanation for this finding is an intestinal loss of albumin, since albuminuria does 
not occur (Martinsson et al. 1974). Recent studies on human blood indicate that $30-40 \%$ of the zinc in serum is firmly bound to $\alpha_{2}$-macroglobulin and the remaining zinc is loosely bound to albumin (Parisi \& Wallee 1970). Therefore it seems likely that an intestinal loss of albumin together with zinc contributed to the decreased serum levels of zinc in group 1. In groups 2 and 3 , the decrease was less pronounced since the albumin levels were higher than in group 1. It should also be noted in pigs with protein malnutrition that a secondary zinc deficiency may develop. This possibly is due to a lack of a transport medium such as serum albumin, which is markedly reduced in such pigs (Platt \& Frankul 1962). Thus protein malabsorption may influence both the levels of albumin and zinc.

The concentration of copper was unchanged in groups 1-3 compared with the control pigs indicating neither a primary deficiency nor intestinal loss of the copper binding protein, ceruloplasmin. This protein has a molecular weight of about 150,000 (Mukasa et al. 1968) and about $90 \%$ of the serum copper is tightly bound to it.

Pigs in group 1 showed an increased concentration of $\alpha_{1}$ antitrypsin in spite of the low molecular weight of this protein. This is probably due to the fact that $\alpha_{1}$-antitrypsin is an "acute phase protein" which increases during infection or cell damage.

The levels of transferrin (mol. wt. 70,000) are greatly decreased in wasting disease which may partly be due, as in the case of albumin, to intestinal loss. Contrary to $\alpha_{1}$-antitrypsin production synthesis of transferrin it not known to be stimulated by cell damage. It is interesting that the levels of $\alpha_{2}$-macroglobulin with a high molecular weight $(900,000)$ are not changed. This finding indicates that intestinal loss of proteins seems to be dependent on their molecular size.

The occurrence of intracellular microorganisms in the ileal epithelium is of special interest with regard to the pathogenesis of regional ileitis. The pigs in group 2 were in a very early stage of the disease, and very few small macro- or microscopic lesions were observed. In all these pigs, intracellular microorganisms were detected. The pigs in group 3 showed a wasting syndrome which precedes regional ileitis. Pigs of this type may develop very early signs of regional ileitis (group 2) if the microorganisms invade the epithelium. The occurrence of intestinal intracellular organisms in pigs of corresponding age is an un- 
usual finding and has only been reported in swine dysentery (Taylor 1971, Glock 1972). It has been observed that conditions such as enteritis or hemorrhagic enteropathies may precede outbreaks of regional ileitis (Nielsen 1971, Rowland \& Rowntree 1972). However, in the present investigation diseased pigs were obtained from herds where diarrhea or other diseases were seen only occasionally after weaning. Therefore, it may be concluded that clinical diseases do not regularly precede outbreaks of regional ileitis.

The etiology of the wasting syndrome which appears to precede regional ileitis is difficult to ascertain, but some form of malabsorption or digestion defect may be involved. Lowered concentrations of serum albumin and zinc are probably secondary events of the disease. It has been shown by Kenworthy et al. (1967) that relatively advanced degenerative changes appear in the small intestinal epithelium in clinically healthy pigs after weaning. A malabsorption syndrome occurs in such pigs (Kenworthy \& Allen 1966). Such a "normal" malabsorption may not be overcome by some pigs but rather will be accelerated, and a wasting syndrome will develop which will precede the invasion of intracellular organisms and the development of regional ileitis.

\section{REFERENCES}

Agergaard, N. \& B. Palludan: Zinkomsætningen hos svin. VII. Alkalisk fosfataseaktivitet $\mathrm{i}$ plasma og væv i relation til zinkstatus. (Zinc metabolism in swine. VII. Alkaline phosphatase activity in plasma and tissues in relation to zinc status). Aarsberetn. Inst. Sterilitetsforskn. 1974, p. 47-59, A/S Carl F. Mortensen, Copenhagen.

Burch, R. E., R. V. Williams, H. K. J. Hahn, M. M. Jeton \& J. F. Sullivan: Serum and tissue enzyme activity and trace-element content in response to zinc deficiency in the pig. Clin. Chem. 1975, $21,568-578$.

Dodd, D. C.: Adenomatous intestinal hyperplasia (proliferative ileitis) of swine. Path. Vet. 1968, 5, 333-341.

Forster, G.: In Methoden der enzymatischen Analyse. Ed. by H. U. Bergmeyer, 2. Auflage, 1970, p. 755.

Glock, R. D.: The pathogenesis of swine dysentry. Proc. Int. vet. Pig Soc., Hannover 1972, p. 62.

Huang, T. C., C. P. Chem, V. Wefler \& A. Raftery: A stable reagent for Lieberman-Burchard reaction applied to rapid serum cholesterol determination. Analyt. Chem. 1961, 33, 1405-1411. 
Jönsson, L. \& K. Martinsson: Regional ileitis in pigs. Morphological and pathogenetical aspects. Acta vet. scand. 1976, 17, 223-232.

Kenworthy, R. \& W. D. Allen: The significance of E. coli to the young pig. J. comp. Path. 1966, 76, 31-44.

Kenworthy, R., J. M. Stubbs \& G. Syme: Ultrastructure of small-intestinal epithelium in weaned and unweaned pigs with postweaning diarrhoea. J. Path. Bact. 1967, 93, 493-498.

Laurell, C.-B.: Quantitative estimation of proteins by electrophoresis in agarose gel containing antibodies. Analyt. Biochem. 1966, 15, $45-52$.

Lawson, G. H. K. \& A. C. Rowland: Intestinal adenomatosis in the pig: Abacteriological study. Res. Vet. Sci. 1974, 17, 331-336.

Martinsson, $K . \&$ K Carlström: The analogues of human $\alpha_{1}$-antitrypsin, $\alpha_{2}$-macroglobulin and pregnancy zone protein $(\mathrm{PZ})$ in swine with some aspects of pregnancy diagnosis. Zbl. Vet.-Med. 1976. In press.

Martinsson, $K$. \& L. Ekman: Behandlingsförsök avseende s.k. pellar bland avvanda grisar. (Experiments of treating wasting pigs after weaning with zinc). Svensk Vet.-Tidn. 1974, 24, 824-828.

Martinsson, K., N. Holmgren, L. Jönsson \& G. Nordström: Några undersökningar över terminal ileit hos grisar. (Some investigations on terminal ileitis in pigs). Svensk Vet.-Tidn. 1974, 10, 347-354.

Mukasa, H., S. Kajiyama, K. Sugiyama, K. Funakubo, M. Itoh, Y. Nosoh \& T. Sato: The subunit structure of porcine ceruloplasmin. Biochim. biophys. Acta (Amst.) 1968, 168, 132-142.

Nielsen, $K$.: Metabolism and distribution of $\mathbf{I}^{131}$-labelled albumin in pigs with gastrointestinal disease. Acta vet. scand. 1966, 7, $321-329$.

Nielsen, $K .:$ Regional enteritis in domestic animals. Regional enteritis (Crohn's disease). Ed. by Engel \& Larsson, Stockholm 1971.

Parisi, A. F. \& B. L. Wallee: Isolation of a zinc $\alpha_{2}$-macroglobulin from human serum. Biochemistry 1970, 9, 2421-2428.

Platt, B. S. \& W. Frankul: The influence of a low-protein diet on the level of zinc and iron in the serum and liver of the pig. Proc. Nutr. Soc. 1962, 21, VII-VIII.

Prasad, A. S., D. Oberleas \& P. Wolf: Changes in trace elements and enzyme activities in tissue of zinc deficient pig. Amer. J. clin. Nutr. 1969, 22, 628-638.

Richkind, M. \& L. E. Edquist: Peripheral plasma levels of corticosteroids in normal beagles and greyhounds measured by a rapid competitive protein binding technique. Acta vet. scand. 1973, 14, 745-757.

Rowland, A. C. \& P. G. M. Rowntree: A hemorrhagic bowel syndrome associated with intestinal adenomatosis in the pig. Vet. Rec. 1972, 91, 235-241. 
Rowland, A. C. \& G. H. K. Lawson: Intestinal adenomatosis in the pig: Immunofluorescent and electron microscopic studies. Res. Vet. Sci. 1974, 17, 323-330.

Scandinavian Committee on Enzymes: Recommended methods for the determination of four enzymes in blood. Scand. J. clin. Lab. Invest. 1974, 33, 291-295.

Taylor, D. J. \& W. F. Blakemore: Spirochaetal invasion of the colonic epithelium in swine dysentery. Res. Vet. Sci. 1971, 12, 177-179.

Thorén-Tolling, $K$. \& K. Martinsson: On the transferrin concentration in serum of sows and growing pigs and in sow colostrum. Acta vet. scand. $1974,15,120-134$.

\section{SAMMANFATTNING}

Hematologisk och biokemisk analys av blod och serum från grisar med regional ileit med särskild hänsyn till patogenesen.

Analysen av serum och blod från grisar med regional ileit och från s.k. „Pellar“ med negativ sektion har utförts. I serum från fall av regional ileit påvisades en signifikant minskad halt av totalprotein, albumin, alkaliskt fosfatas och zink. Antalet vita blodkroppar samt halten cortisol och $\alpha_{1}$-antitrypsin var signifikant ökad. I serum från s.k. „Pellar" med antingen negativ sektion eller i mycket tidigt stadium av regional ileit påvisades samma avvikelser som dock var mindre uttalade. Ett „wasting syndrome“ (Pelleutseende) efter avvänjning anses predisponera för uppkomsten av regional ileit. Angående etiologin till regional ileit diskuteras betydelsen av malabsorption och „wasting syndrome“ i kombination med invasion av intracellulära mikroorganismer i epitelet av ileum.

(Received March 24, 1976).

Reprints may be requested from: Kjell Martinsson, the Department of Medicin I, Royal Veterinary College, S-104 05 Stockholm 50, Sweden. 